\title{
Proposal for an analytical model of materiality in the Global Reporting Initiative Standards reports
}

\author{
lgor Laguna Vieira ${ }^{a *}$ (D), Elmo Rodrigues da Silva (D), Luiz Carlos de Martini Junior ${ }^{\mathrm{a}}$ (D), \\ Luis Alberto Duncan Rangel ${ }^{\mathrm{b}}$ \\ ${ }^{a}$ Universidade do Estado do Rio de Janeiro, Rio de Janeiro, RJ, Brasil \\ bUniversidade Federal Fluminense, Volta Redonda, RJ, Brasil \\ *igor_laguna@hotmail.com
}

\begin{abstract}
Paper aims: This study proposes, applies, and discusses a model based on the analytic hierarchy process (AHP) method with the objective of assessing the issue of materiality of sustainability reports in the Global Reporting Initiative (GRI) model of civil construction companies.

Originality: The published literature contains few studies that propose quantitative models for the assessment of materiality for sustainability reports. To address this data gap, the present research suggests new paths.
\end{abstract}

Research method: After the hierarchical structure of the model had been developed, specialists were asked to prioritize the criteria and sub-criteria in their orders of preference. Their decisions were collected through a questionnaire and the responses were included in the model using the individual aggregation of priorities method applied to the AHP.

Main findings: It was concluded that there is scope for improving the quality of sustainability reports, as there are companies that fail to disclose relevant topics according to the judgment of the specialists consulted in this study.

Implications for theory and practice: The AHP method with absolute measurement proved to be an efficient model, mainly because it allows for weighting of criteria and sub-criteria, demonstrating that it is useful for comparing the materiality of company reports.

Keywords

Multi-criteria decision making. Construction sector. Analytic hierarchy process. GRl. Sustainable development.

How to cite this article: Vieira, 1. L., Silva, E. R., Martini Junior, L. C., \& Rangel, L. A. D. (2021). Proposal for an analytical model of materiality in the global reporting initiative standards reports. Production, 31, e20210003. https:// doi.org/10.1590/0103-6513.20210003

Received: Jan. 28, 2021; Accepted: May 05, 2021.

\section{Introduction}

\subsection{Sustainable development}

The concept of sustainable development has been the focus for decision makers in organizations. According to the Brundtland Report, sustainable development meets the economic needs of the current generation without compromising the ability of future generations to meet their needs (World Commission on Environment and Development, 1987).

Following this concept and committed to global transformation, the " 2030 Agenda", launched in 2015 by the United Nations (UN), recognizes the need to change the trajectory of countries and regions (Spangenberg, 2016; United Nations, 2015). The "Triple Bottom Line", another important concept, addresses the three dimensions of sustainability: environmental, economic, and social (Elkington, 1997). 
Presently, many companies recognize and monitor these three dimensions using sustainability indicators, which provide information on how the company contributes to sustainable development. As sustainability is characterized by both quantitative and qualitative aspects, multi-criteria decision making (MCDM) methods can be useful for prioritizing topics based on the company's overall impacts (Govindan et al., 2015a, b; Ziout et al., 2013). Such methods can improve decision-making by breaking down the evaluation of alternatives and systematically accounting for conflicting criteria (Durbach \& Stewart, 2012). In addition, the MCDM allows a broader view from varying perspectives and supports the development of sustainable strategies (Kucukvar et al., 2014; Manzardo et al., 2014). MCDM methods are commonly used in the field of sustainability (Boral et al., 2020; Cegan et al., 2017; Choudhury et al., 2020; Man et al., 2020; Mohammed, 2020; Schlickmann et al., 2020).

\subsection{Sustainability in the civil construction sector}

Awareness of socioenvironmental issues led the civil construction sector, as well as other industries, to participate in the debate on sustainability and to initiate strategies to respond to the challenges of sustainable development. Notably, the civil construction sector has strategic importance, presenting itself as a strong indicator of economic growth (Liu et al., 2020).

However, like so many other activities, this sector causes socio-environmental impacts, from the manufacture of raw materials, to changes in the region where the construction is located. On a global scale, the construction industry is responsible for consuming much of the planet's water, energy produced, and available raw materials. It also emits a significant amount of greenhouse gases into the atmosphere and is responsible for a substantial generation of solid waste (Ecorys, 2014; Willmott Dixon, 2010).

Additionally, the construction sector is a major contributor to occupational accidents and diseases, with its rate considered higher than the average for other industries (Poghosyan et al., 2020; Trinh et al., 2019). Regarding the economic part of the triple bottom line, there is a growing consensus within and outside the construction industry, that corruption and other unethical practices are endemic to the sector, as the complex and costly nature of construction projects gives rise to the potential for corruption (Ameh \& Odusami, 2010; Ameyaw et al., 2017; Gunduz \& Önder, 2013).

\subsection{Sustainability reports and materiality}

Traditional accounting and financial reporting fail to adequately measure the socio-economic and environmental impacts of organizations, leading to the need for more comprehensive reporting. Companies, including those in the civil construction sector, aiming to manage their business based on the environmental-social-economic framework, increasingly monitor, quantify, and disclose more data to stakeholders through sustainability reports. To create these reports, we have an example of the Global Reporting lnitiative (GRI) model, which is the most common model adopted by organizations worldwide (Mancini \& Sala, 2018; Moggi, 2019; Safari \& Areeb, 2020; Talbot \& Boiral, 2018).

Transparent communication improves the credibility of a company's environmental and social commitments and favors long-term value creation processes (Schmeltz, 2014). However, organizational characteristics, such as business model, size, property held, and social and cultural contexts, affect the significance of a company's impacts and the expectations of its stakeholders in relation to sustainability. For this reason, not all sustainability topics have the same relevance for all companies (Wicher et al., 2019).

The GRI Sustainability Reporting Guidelines emphasize the importance of focusing on the "material" sustainability topics, that is, those that truly reflect the organization's significant economic, environmental, and social impacts. The Global Reporting Initiative $(2016$, p. 10) defines materiality as "the principle that determines which relevant topics are sufficiently important that it is essential to report on them." This is the definition for materiality used in this article.

Sustainability reports cover multiple topics including energy, biodiversity, human rights, and governance. As the interested groups are very diverse, it is a challenge for organizations to determine what information is necessary (Reimsbach et al., 2019). To solve this problem, "materiality analysis" is applied, which aims to determine the relevance of a given aspect for an organization and its stakeholders (Calabrese et al., 2016). In order to carry out such an analysis, the organization must involve different interested groups, seeking to integrate different perceptions of economic, environmental, and social issues. These perceptions will serve to indicate what should be reported, as well as how the organization should act in the face of issues related to sustainable development.

However, it is important to note that the quality of this analysis varies. As each organization has its own method for determining which information is material, a notable divergence of the contents of the sustainability 
reports released is expected (Edgley et al., 2015; Lai et al., 2017). Additionally, materiality analysis is a process characterized by subjectivity, as opinions, experiences, and expectations directly influence the assessment of the relevance of sustainability aspects. Decision-making involving subjective judgments is considered uncertain and imprecise (Costa \& Menichini, 2013; Yan \& Ma, 2015).

It is worth mentioning that the credibility and reliability of sustainability reports have recurrently resulted in criticism in scientific literature. An issue raised frequently is that sustainability reports can be used as a facade of legitimacy, or as an attempt to practice greenwashing, by highlighting aspects indicating good performance, while suppressing negative indicators with the aim of presenting a socio-environmentally responsible image that may be inaccurate (Brooks \& Oikonomou, 2018).

\subsection{Research gap and article objectives}

The published literature contains a limited number of studies that propose models, primarily quantitative, for assessing materiality in sustainability reports. This has been noted by Calabrese et al. (2019). In these studies, the proposed models are not used for the evaluation of previously published reports, but as a guideline for the production of new reports. In addition, none of these studies are aimed at the construction sector. Such limitations of the previous literature imply that a materiality analysis model must be immediately developed for the sector, primarily to analyze previously published reports.

In order to address this research gap, specifically focusing on the issue of subjectivity in the assessment of materiality, and to assist in the critical analysis of sustainability reports, this study proposes a new path: an analytical model of materiality is proposed based on the MCDM method "Analytic Hierarchy Process (AHP) with absolute measurement" (Saaty, 2006), which is applied to sustainability reports from Latin American civil construction companies. These results will be discussed. The civil construction sector was selected as the object of this research due to its great potential to generate impacts for sustainable development.

\section{Literature review on the topics related to the proposed method}

\subsection{AHP method}

AHP (Saaty, 1980) is a decision-making approach used to solve complex problems with multiple criteria involving qualitative judgments. It is a subjective tool that is widely used to assign priority rankings to decision criteria and sub-criteria (Zhao et al., 2016).

To make a well informed decision using the AHP method, Saaty (2008) points out that a decision maker needs to generate priorities by breaking down the decision into the following steps:

i. Defining the problem and objective to be achieved.

ii. Structuring the decision hierarchy with the objective defined at the top, followed by intermediate levels with criteria on which the subsequent elements depend, down to the lowest level (which, in general, is a set of alternatives).

iii. Building a set of peer comparison matrices. To make such comparisons, decision makers must use a number scale to indicate how many times an element is dominant over another element, in relation to the attribute or indicator they are compared with. Table 1 shows the paired comparison scale.

iv. Adopting the priorities from the comparisons and assigning rankings to each of them. This procedure is to be performed for each element. For each element in the following levels, the weighted values are to be added to derive an overall score. The addition of the weighted values was continued until the rankings of the alternatives at the lowest level were obtained.

Table 1. Saaty fundamental scale.

\begin{tabular}{|c|c|c|}
\hline Intensity of Importance & Definition & Explanation \\
\hline 1 & Equal Importance & Two activities contribute equally to the objective. \\
\hline 3 & Moderate importance & Experience and judgement slightly favour one activity over another. \\
\hline 5 & Strong importance & Experience and judgement strongly favour one activity over another. \\
\hline 7 & $\begin{array}{c}\text { Very strong or } \\
\text { demonstrated importance }\end{array}$ & $\begin{array}{c}\text { An activity is favoured very strongly over another; its dominance demonstrated in } \\
\text { practice. }\end{array}$ \\
\hline 9 & Extreme importance & $\begin{array}{l}\text { The evidence favouring one activity over another is of the highest possible order of } \\
\text { affirmation. }\end{array}$ \\
\hline $2,4,6,8$ & Intermediate values & \\
\hline
\end{tabular}


The AHP method is scalable, easily adjustable to tackle various sized issues, and requires minimal input data. However, it has some limitations as it does not consider the interdependence between criteria and alternatives at the same hierarchical level. In addition, it can lead to inconsistencies in the judgments as well as a reversal of priority rankings when new alternatives are included (Saad et al., 2019). The mathematical equations of the method can be found in literature (Ocampo, 2018; Tramarico et al., 2019; Yu et al., 2020), therefore are not duplicated here.

Notably, the method is qualitative and subjective, and therefore, contradictions may occur. Judgments, even if performed by specialists, need to be validated, and a consistency procedure within the comparison methodology should be followed.

Such consistency depends on the ability of the judges to express coherent comparisons in the sense of transitivity: if option $A$ is rated as $k_{1}$ times more important than option $B$ and $k_{2}$ times more important than option $\mathrm{C}$, and if option B was considered $\mathrm{k}_{3}$ times more important than option $\mathrm{C}$, how close will this latter ratio $\mathrm{k}_{3}$ be to $\mathrm{k}_{1} \mathrm{k}_{2}$ ?

Thus, the congruence of the analysis obtained by the AHP method must be validated based on the consistency ratio (CR). Saaty considers that a value less than 10\% indicates an adequate consistency of judgments. Above that value, judgments must be reconsidered (Saaty, 1980).

It is common for the decision makers judgements to lack confidence. Thus, a sensitivity analysis must be performed to guarantee the reliability of the results (final score). If small changes in the weighting of a criterion (or sub-criterion) results in significant changes to the final scores, it is stated that the results are sensitive to the criterion. This means that the criterion weighting must be precisely determined (Simanaviciene \& Ustinovichius, 2010). If the results obtained from the sensitivity analysis are acceptable, the decision maker can proceed to the final step, which classifies the candidate evaluation according to the obtained aggregate scores.

In the AHP approach with the use of absolute measurement, paired comparisons between criteria and sub-criteria are made as per the classic approach. However, the elements on the lowest level of the hierarchy (usually alternatives) are not compared with each other but they are categorized using elements of an evaluation scale (Saaty, 2006).

For Saaty (2008), one of the main advantages of this approach is that it reduces the number of necessary paired comparisons, which is particularly useful when there are many alternatives, or new alternatives to add after assigning rankings to the criteria and sub-criteria. In addition, there is no order inversion when new alternatives are included.

Rahman et al. (2019) used AHP with absolute measurement to propose a system of business excellence aimed at the Bangladesh hotel industry. In another example of the application of this approach, Petrillo et al. (2017) developed a "carpooling system" platform model based on different criteria.

\subsubsection{AHP method for group decisions}

It is natural that there are inconsistencies in the decision-making process when the issues are analyzed by a group of people. A group decision involves the subjectivity of each individual on a wide range of issues. Such a situation can culminate in conflicts that are not always possible to be resolved.

The behavior of a specific group will determine how the information is analyzed and aggregated within the AHP. The two most commonly used methods for calculating collective priorities in decision making with multiple factors are as follows: i) aggregation of individual judgments (AlJ) - in the case of groups that act homogeneously and ii) aggregation of individual priorities (AIP) - for groups that prefer to maintain the analysis of each individual (Ramanathan \& Ganesh, 1994). Notably, it is possible to assign different weightings to decision makers or else consider them of equal importance within the process, both for the AlJ and the AIP.

As an example of the application of the AIP, Martin-Utrillas et al. (2014) used the method to aggregate the opinion of experts and develop a model which could select the optimum combination of techniques to be applied in the decontamination of leachate in landfills.

\subsection{Global reporting initiative}

The United Nations Environment Program (UNEP), in association with the Coalition for Environmentally Responsible Economics (CERES), launched the Global Reporting lnitiative (GRI) in 1997 to improve the quality, structure and coverage of sustainability reports (Global Reporting lnitiative, 2020). Such reports are the focus of the guidelines. 
The GRI sustainability reporting guidelines combine the reporting of financial and non-financial information in a standardized structure, resulting in a comprehensive characterization of a company's sustainability performance in terms of its economic, environmental, and social impacts (Global Reporting Initiative, 2021a). Such guidelines offer companies a number of potential advantages, such as allowing standardization of reporting content, improving relationships with stakeholders, and comparing organizations' practices and performance (Calabrese et al. 2016; Safari \& Areeb, 2020; Talbot \& Boiral, 2018; Wagner \& Seele, 2017).

Since its introduction in 1997, the GRI has launched several editions of guidelines. The fourth generation (G4), launched in 2013, started to emphasize the concept of materiality, encouraging reporting organizations to provide only information that truly reflects their economic, environmental, and social impacts, based on a dialogue with their stakeholders and an evaluation of the organization's impacts (Global Reporting Initiative, 2013). According to Global Reporting Initiative (2016, p. 10), "not all material topics are of equal importance, and the emphasis within a report is expected to reflect their relative priority".

In October 2016, the GRI launched a new version of the guidelines: the GRI Standards. Developed by the Global Sustainability Standards Board (GSSB), they allow organizations to publicly disclose their economic, environmental, and social impacts through disclosures (former indicators in GRI G4). The GRI Standards include the main concepts of the GRI G4 guidelines, which have been improved to allow a more flexible structure, clearer requirements, and simpler language (Global Reporting Initiative, 2020).

The GRI advised organizations to adopt the new standard in their sustainability reports as early as 2016 . After July 2018, reports and other materials that refer to the GRI must adopt the new structure. Therefore, since that date, GRI G4 guidelines can no longer be used (Global Reporting Initiative, 2018).

According to the GRI database, since these guidelines emerged, 485 companies in the construction sector around the world have released their reports following the format suggested by the GRI. In Latin America, throughout the period of existence of these guidelines, 101 organizations have completed their reports following this guidance (Global Reporting Initiative, 2021b).

\subsection{Previous studies on models for analyzing materiality}

The studies described below were located using the search strategy detailed in section 3.1.

Through these search strategies, 177 articles and 45 theses or dissertations were found. Duplicates were excluded, and the studies were filtered, retaining only those where the focus was on materiality in sustainability reports. Thus, 43 studies were selected, including 41 journal articles, a master's dissertation, and a doctoral thesis. Regarding the analysis of materiality to determine the content of these reports, only 4 studies presented in this review proposed models that assist in such an analysis. Table 2 provides a summary of the studies that developed models for analyzing materiality.

Table 2. Summary of studies that developed models for materiality analysis.

\begin{tabular}{lcccc}
\hline Source & $\begin{array}{c}\text { Does the study use } \\
\text { methods of MCDM? }\end{array}$ & $\begin{array}{c}\text { Focus on which version of } \\
\text { the GRI guidelines? }\end{array}$ & $\begin{array}{c}\text { Was the proposed method } \\
\text { used to analyze reports } \\
\text { already published? }\end{array}$ & $\begin{array}{c}\text { Sector(s) of the } \\
\text { company(ies) analyzed in } \\
\text { the study }\end{array}$ \\
\hline $\begin{array}{l}\text { Calabrese et al. (2015) } \\
\text { Calabrese et al. (2016) }\end{array}$ & No & GRl G4 & No & Retail \\
Water \\
Bellantuono et al. (2016)
\end{tabular}

A literature review indicates that the published studies containing models to assist in the analysis of materiality do not propose examining published reports. In addition, the focus lies on the GRI G4 guidelines, which are no longer in effect, and none of the studies are applied to the civil construction sector. In other words, there is an important gap in the literature: a model is needed to analyze materiality in previously published reports, which focuses on the current GRI Standards, and is directed toward the civil construction sector. 


\section{Research method}

\subsection{Strategies to search for previous studies on models for analyzing materiality}

The database for scientific articles was selected after research in the "Portal de Periódicos da Coordenação de Aperfeiçoamento de Pessoal de Nível Superior - CAPES Portal.” The Scopus base was selected because it had the greatest number of results. We attempted to use other databases to include articles in Portuguese, without success, indicating that this research topic is not yet substantially present in Portuguese journals. The "Biblioteca Digital Brasileira de Teses e Dissertações (BDTD)" was also consulted in order to increase the breadth of research in national studies.

Our literature review has a number of limitations. First, only studies published in the databases described above were included in this research. In other words, reports or documents from the "gray" literature sector, chapters from books, or articles from events have been excluded. The starting date for this review was 2015.

For the selection of articles, the following descriptors were used in the CAPES Portal, seeking to maximize the results: 1) "Any article containing "sustainability" AND "in the subject contains "materiality"; 2) "Any article containing "sustainability" AND "in the title contains "materiality". At BDTD, the descriptors that returned the most relevant results were as follows: "All fields: "materiality"” and "All fields: "sustainability report".

Duplicates were eliminated, and the materials were read in full, excluding those that did not focus on the "materiality" theme. From the remaining studies, those that proposed models for materiality analysis were selected.

\subsection{Sector and companies chosen to apply the proposed model}

For this study, a model for analyzing the materiality of sustainability reports was proposed, which was applied to civil construction companies in Latin America. This sector was considered as the best example available, due to its economic importance and its high potential to generate socio-environmental impacts.

The selected companies published their sustainability reports in the GRI Standards model, published on the GRI website in 2019. The filters (Sector $\rightarrow$ Construction; Region $\rightarrow$ Latin America and the Caribbean; Report Type $\rightarrow$ GRI Standards; Report Year $\rightarrow$ 2019) resulted in the selection of 16 organizations. Table 3 shows the companies selected for this study.

Table 3. Selected companies.

\begin{tabular}{cc}
\hline Company & Country \\
\hline Geométrica (A) & Peru \\
HLF Romero (B) & Colombia \\
SMC $\odot$ & Peru \\
Smont \& Aragon (D) & Peru \\
Graña y Montero (E) & Peru \\
Inmobiliaria Vinte (F) & Mexico \\
COSAPI (G) & Peru \\
Ferzamate SAC (H) & Peru \\
Construcciones El Condor (1) & Colombia \\
Concesión La Pintada (J) & Colombia \\
Percerhad SAC (K) & Peru \\
Volcan (L) & Chile \\
MLugo (M) & Peru \\
Negociaciones Vimer ElRL (N) & Peru \\
Comercializadora S\&E (O) & Peru \\
Concesion Alto Magdalena (P) & Colombia \\
\hline
\end{tabular}

\subsection{Hierarchical structure of the problem}

The methodology used in this research was based on the multicriteria AHP method, using the absolute measurement approach. This method was chosen because it reflects the concerns identified, and offers a logical procedure to follow for comparing factors with the objective of establishing priorities and assigning weightings that reflect the relative importance of sustainability issues. Furthermore, the AHP method is a well-established model, used within academia and industry. The method incorporates additive and compensatory mechanisms 
and allows for the ordering of alternatives. The absolute measurement approach was used to reduce the number of necessary paired comparisons, as there are many alternatives and there is still the possibility of using the model later to evaluate reports not included in this research.

Previous studies have shown that this method is adequate for representing the structure of sustainability issues presented in the GRI guidelines (Calabrese et al., 2016; Ziout et al., 2013). Regarding the triple bottom line, the GRI reporting structure allows for clear structuring of the economic, environmental, and social elements and their associated subject matters, (former aspects in GRI G4), with each topic referring to a single GRl series.

The proposed method uses the GRI structure within the AHP in terms of criteria (dimensions) and decision sub-criteria (topics), offering a useful tool to analyze the materiality of sustainability reports. The assessment is summarized according to Figure 1, in which its hierarchical structure is represented, which is the same structure of the GRI standards.

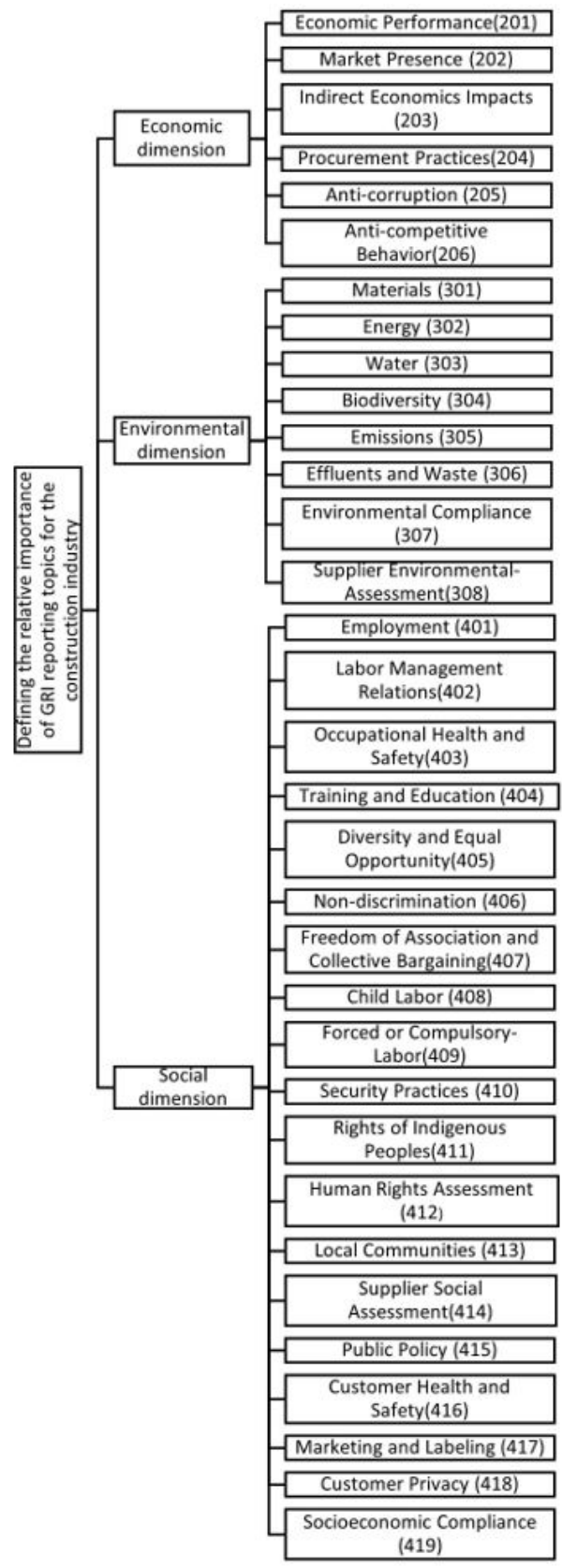

Figure 1. Hierarchical structure of the assessment. 
After the hierarchical structure of the assessment was built, 17 specialists - all graduates and working in the civil and/or environmental sectors - were asked to make comparisons to rank the relative importance of the topics used in the GRI reporting model for civil construction companies. The comparisons were collected via a questionnaire, and the answers were collated using the AIP method applied to AHP. The numerical scale of Saaty (Table 1) was presented to the specialists, which allowed them to compare the topics in the hierarchy (Figure 1).

Based on these comparisons, it was possible to assign degrees of importance to the sustainability topics in relation to the hierarchical structure's objective. As the absolute measurement approach was used, there was no need for comparisons between the alternatives. In addition, the consistency ratio was examined to verify the consistency of the evaluations by the specialists. According to Saaty (1980), the consistency ratio should not exceed 10\%, with this value being adhered to in the decision matrices developed as a result of this research.

It was decided to give the same weight to the "Economic", "Environmental" and "Social" criteria, based on the triple bottom line concept, in which dimensions are equally important for sustainable performance (Elkington, 1997).

The computer program Expert Choice ${ }^{\circledR}$ (2004) was used to perform the calculations. This program has several features and functions, such as graphical sensitivity analyses, which allow a broad understanding of the results obtained, in addition to automatically calculating the consistency ratio of the judgments made.

To obtain the numerical values of the absolute evaluation scale, a comparison matrix was constructed between their degrees of intensity (e.g. "Has" or "Does not have" such a topic in their report).

The last stage of the research enables a ranking of the companies analyzed, in relation to the materiality of their reports, based on the sum of the weights attributed to each topic. This phase included the analysis of the data obtained from the companies' sustainability reports, using the aforementioned software.

\section{Results}

Tables 4-6 present the topics disclosed by the surveyed companies, obtained from their GRI sustainability reports for the year 2019.

For the sub-criteria, Tables 7-9 present the weights assigned by the specialists for the topics of the Economic, Environmental, and Social elements, respectively.

Following the specialists' comparisons for each sub-criterion, the values of the absolute measurement evaluation scale were input into the matrix, presented in Table 10:

Table 11 shows the general ranking of materiality for the companies analyzed, after the calculations were performed with the aid of Expert Choice ${ }^{\circledR}$ (2004).

The sensitivity analysis for each criterion (economic, environmental, and social) was completed using Expert Choice ${ }^{\circledR}$ (2004), results are presented as Figure 2-4.

In the case of the "Economic" criterion, the first inversion of positions occurs with an increase in weighting from $33.3 \%$ to $38.6 \%$ (16\% variation).

In the case of the "Environmental" criterion, the first inversion of positions occurs with an increase in weighting from $33.3 \%$ to $40.0 \%$ (20\% variation).

In the case of the "Social" criterion, the first inversion of positions occurs with an increase in weighting from $33.3 \%$ to $36.9 \%$ ( $11 \%$ variation).

Table 4. Topics published by companies (Economic).

\begin{tabular}{|c|c|c|c|c|c|c|c|c|c|c|c|c|c|c|c|c|c|}
\hline & \multicolumn{17}{|c|}{ COMPANIES } \\
\hline & A & B & C & D & E & $\mathrm{F}$ & G & H & 1 & $\mathbf{J}$ & K & $\mathrm{L}$ & M & $\mathrm{N}$ & 0 & $P$ & \\
\hline \multirow{6}{*}{ TOPICS } & 201 & & $x$ & $x$ & & & $\mathrm{x}$ & $x$ & $x$ & $x$ & & $x$ & $x$ & $x$ & $x$ & $x$ & $x$ \\
\hline & 202 & & & & & & & $x$ & & & $x$ & $x$ & & & & & \\
\hline & 203 & & & & & $x$ & & & & & $X$ & & & & & $x$ & \\
\hline & 204 & & & & & $x$ & & $x$ & & & $x$ & & & & & & \\
\hline & 205 & $x$ & & $X$ & $x$ & $X$ & & $x$ & $x$ & & $X$ & $x$ & & & $x$ & $x$ & $x$ \\
\hline & 206 & & & $x$ & & & & & $x$ & & & & & & & & \\
\hline
\end{tabular}


Table 5. Topics disclosed by companies (Environmental).

\begin{tabular}{|c|c|c|c|c|c|c|c|c|c|c|c|c|c|c|c|c|c|}
\hline & \multicolumn{17}{|c|}{ COMPANIES } \\
\hline & A & B & C & D & E & $\mathrm{F}$ & G & $\mathrm{H}$ & 1 & J & K & $\mathrm{L}$ & M & $\mathrm{N}$ & 0 & $\mathrm{P}$ & \\
\hline \multirow{8}{*}{ TOPICS } & 301 & & & $x$ & & & & & & $x$ & & & $x$ & & & $x$ & \\
\hline & 302 & & & & & $x$ & & $x$ & & & $x$ & & $x$ & $x$ & & & $x$ \\
\hline & 303 & & & & & & & $x$ & & & $X$ & & $x$ & & & & \\
\hline & 304 & & & & & & & $x$ & & & $X$ & & & & & & \\
\hline & 305 & & & & & $x$ & & $x$ & & $x$ & $X$ & & $x$ & & $x$ & & $x$ \\
\hline & 306 & & & & & $x$ & & $x$ & & & $x$ & & $x$ & $x$ & & $x$ & \\
\hline & 307 & $X$ & $x$ & $X$ & $x$ & & & & $X$ & $x$ & $x$ & $x$ & & & & $X$ & \\
\hline & 308 & & & $X$ & & $x$ & & & & & $x$ & & $x$ & & & & \\
\hline
\end{tabular}

Table 6. Topics disclosed by companies (Social).

\begin{tabular}{|c|c|c|c|c|c|c|c|c|c|c|c|c|c|c|c|c|c|}
\hline & \multicolumn{17}{|c|}{ COMPANIES } \\
\hline & A & B & C & D & E & $\mathrm{F}$ & G & H & 1 & J & K & $\mathrm{L}$ & M & $\mathrm{N}$ & 0 & $P$ & \\
\hline \multirow{19}{*}{ TOPICS } & 401 & $x$ & & $\mathrm{x}$ & $x$ & & $x$ & & & $x$ & $x$ & $x$ & $x$ & X & & & \\
\hline & 402 & & & & & & & & & & $x$ & & & & & & \\
\hline & 403 & $x$ & $x$ & $x$ & $x$ & $x$ & & $x$ & $x$ & $x$ & $x$ & $x$ & $x$ & $x$ & $x$ & $\mathrm{x}$ & $x$ \\
\hline & 404 & & & & & $x$ & & $x$ & & $x$ & $x$ & & $x$ & $X$ & $x$ & $x$ & \\
\hline & 405 & & & & & & $x$ & & & & $\mathrm{x}$ & & $x$ & & & & \\
\hline & 406 & & & & & & & $x$ & & & & & & & & & \\
\hline & 407 & & & & & & & $x$ & & & & & & & & & \\
\hline & 408 & & & & & & $x$ & $x$ & & & & & & & & $\mathrm{x}$ & \\
\hline & 409 & & & & & & & $x$ & & & & & & & & $\mathrm{x}$ & \\
\hline & 410 & & & & & & & & & & & & & & & $x$ & \\
\hline & 411 & & & & & & & & & & & & & & & & \\
\hline & 412 & & & & & & & & & & & & & & & & \\
\hline & 413 & & & $x$ & & & $x$ & $x$ & $x$ & $x$ & X & & $x$ & & $x$ & & $\mathrm{x}$ \\
\hline & 414 & & $x$ & & & $x$ & & $x$ & & & $X$ & & $x$ & & & & \\
\hline & 415 & & & & & & & $x$ & & & $x$ & & & & & & \\
\hline & 416 & & & & & & & & & & & & & & & & \\
\hline & 417 & & & & & & & & & & & & $x$ & & & & \\
\hline & 418 & & & & & & & & & & & & & & & & \\
\hline & 419 & $x$ & & $x$ & $x$ & & & & $x$ & $x$ & $\mathrm{X}$ & $x$ & & & & & \\
\hline
\end{tabular}

Table 7. Weights assigned by experts in the Economic Series.

\begin{tabular}{ccccc}
\hline Dimension & Weight & Topic & Weight within dimension & Overall weight \\
\hline & & 201 & 0.140 & 0.047 \\
& & 202 & 0.127 & 0.042 \\
Economic & \multirow{2}{*}{0.333} & 203 & 0.115 & 0.038 \\
& & 204 & 0.126 & 0.042 \\
& 205 & 0.345 & 0.115 \\
& 206 & 0.148 & 0.049 \\
\hline
\end{tabular}

Table 8. Weights attributed by specialists in the Environmental Series.

\begin{tabular}{|c|c|c|c|c|}
\hline Dimension & Weight & Topic & Weight within dimension & Overall weight \\
\hline \multirow{8}{*}{ Environmental } & \multirow{8}{*}{0.333} & 301 & 0.068 & 0.023 \\
\hline & & 302 & 0.063 & 0.021 \\
\hline & & 303 & 0.218 & 0.073 \\
\hline & & 304 & 0.158 & 0.053 \\
\hline & & 305 & 0.120 & 0.040 \\
\hline & & 306 & 0.182 & 0.061 \\
\hline & & 307 & 0.126 & 0.042 \\
\hline & & 308 & 0.065 & 0.022 \\
\hline
\end{tabular}


Table 9. Weights assigned by specialists in the Social Series.

\begin{tabular}{|c|c|c|c|c|}
\hline Dimension & Weight & Topic & Weight within dimension & Overall weight \\
\hline & & 401 & 0.060 & 0.020 \\
\hline & & 402 & 0.025 & 0.008 \\
\hline & & 403 & 0.101 & 0.034 \\
\hline & & 404 & 0.038 & 0.013 \\
\hline & & 405 & 0.081 & 0.027 \\
\hline & & 406 & 0.056 & 0.019 \\
\hline & & 407 & 0.020 & 0.007 \\
\hline & & 408 & 0.130 & 0.043 \\
\hline & & 409 & 0.116 & 0.039 \\
\hline \multirow[t]{10}{*}{ Social } & 0.333 & 410 & 0.034 & 0.011 \\
\hline & & 411 & 0.037 & 0.012 \\
\hline & & 412 & 0.032 & 0.011 \\
\hline & & 413 & 0.053 & 0.018 \\
\hline & & 414 & 0.023 & 0.008 \\
\hline & & 415 & 0.030 & 0.010 \\
\hline & & 416 & 0.064 & 0.021 \\
\hline & & 417 & 0.011 & 0.004 \\
\hline & & 418 & 0.036 & 0.012 \\
\hline & & 419 & 0.053 & 0.018 \\
\hline
\end{tabular}

Table 10. Absolute measurement evaluation scale.

\begin{tabular}{cccc}
\hline & Has & Does not have & Weight \\
\hline Has & 1 & 9 & 0.900 \\
Does not has & $1 / 9$ & 1 & 0.100 \\
\hline
\end{tabular}

Table 11. Materiality ranking.

\begin{tabular}{|c|c|c|}
\hline Ranking & Company & Pointing \\
\hline $1^{\circ}$ & G & 0.129 \\
\hline $2^{\circ}$ & J & 0.126 \\
\hline $3^{\circ}$ & 0 & 0.083 \\
\hline $4^{\circ}$ & $\mathrm{L}$ & 0.077 \\
\hline $5^{\circ}$ & E & 0.070 \\
\hline $6^{\circ}$ & C & 0.066 \\
\hline $7^{\circ}$ & $\mathrm{H}$ & 0.057 \\
\hline $8^{\circ}$ & K & 0.053 \\
\hline $9^{\circ}$ & 1 & 0.047 \\
\hline $10^{\circ}$ & $P$ & 0.046 \\
\hline \multirow[t]{2}{*}{$11^{\circ}$} & $\mathrm{F}$ & 0.044 \\
\hline & $\mathrm{N}$ & \\
\hline \multirow[t]{3}{*}{$13^{\circ}$} & A & 0.041 \\
\hline & $\mathrm{D}$ & \\
\hline & M & \\
\hline $16^{\circ}$ & B & 0.033 \\
\hline
\end{tabular}



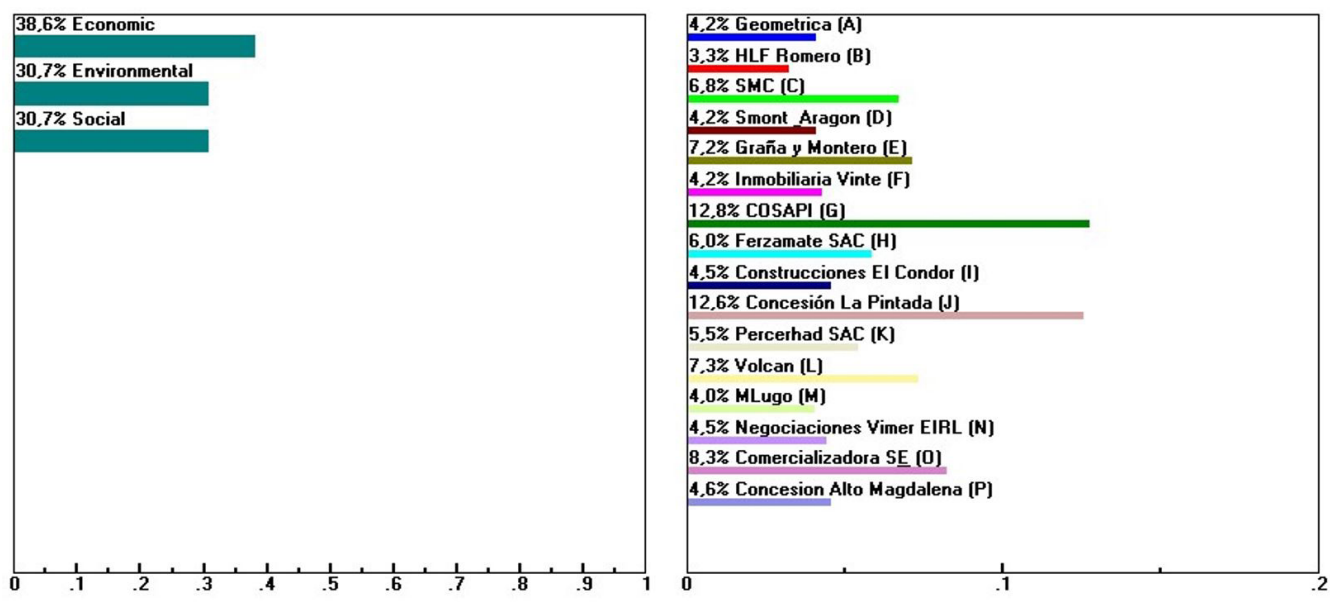

Figure 2. Sensitivity analysis for the "Economic" criterion.

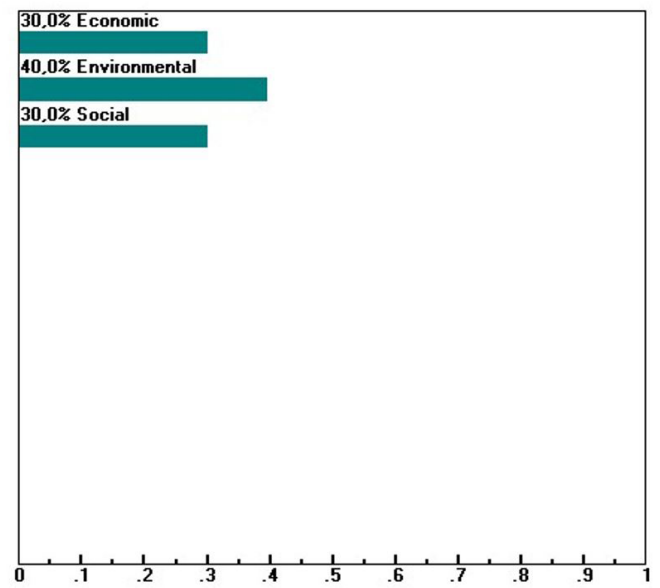

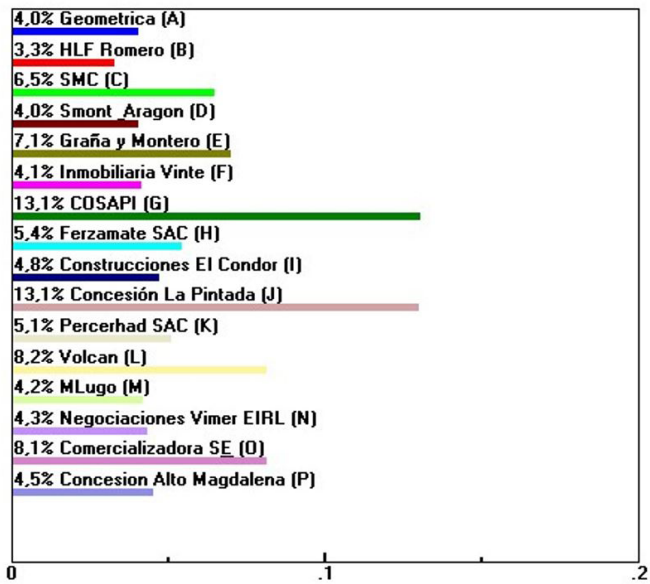

Figure 3. Sensitivity analysis for the "Environmental" criterion.

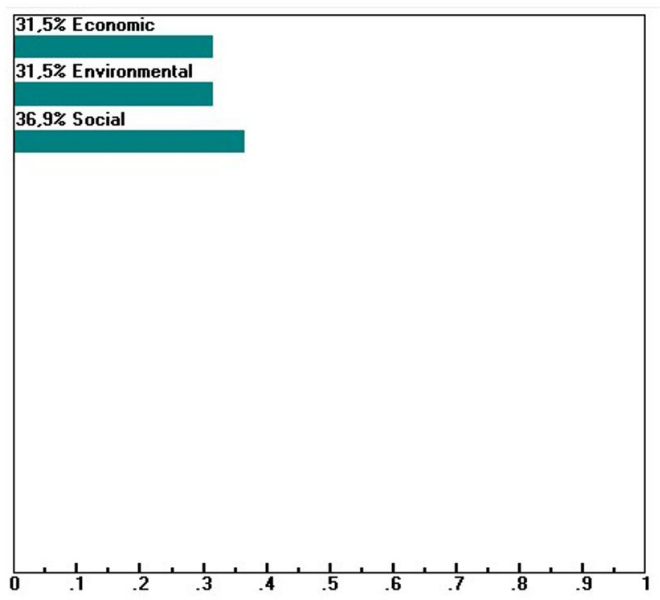

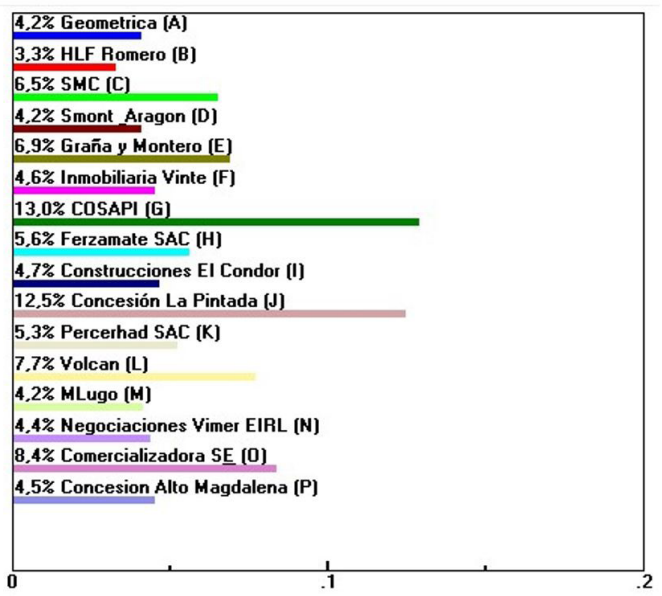

Figure 4. Sensitivity analysis for the "Social" criterion. 


\section{Discussion}

A possible reason for the variation in the quality of the materiality analysis is the absence of consistent structures to carry out such an analysis. The proposal of models for conducting materiality analysis can reduce the subjectivity present in the process, as noted by Costa \& Menichini (2013) and Yan \& Ma (2015). However, it was found, through a literature review, that there are few studies that propose to fill this gap, which has also been noted by Calabrese et al. (2019).

There is also a shortage of models allowing the analysis of reports already published, verifying whether the disclosed aspects are the most sensitive for the sector in which the organization operates, which could indicate greenwashing (Brooks \& Oikonomou, 2018). It was also found that the models in the literature do not consider the updated version of the GRl guidelines - GRl Standards (Global Reporting Initiative, 2020). To fill these gaps, a model for analyzing materiality in GRI reports was proposed in this paper and applied to Latin American companies in the civil construction sector for the year 2019.

Of the Latin American companies that published their sustainability reports in 2019 on the GRI website, Peruvian companies were the most common. Of the sixteen companies studied, ten were Peruvian, four were Colombian, one Chilean, and one Mexican. The absence of companies from countries with large triple bottom line dimensions and which are economically important in the region, such as Brazil and Argentina, is striking. However, the investigation into the absence of such companies was not the focus of this research.

With regard to the application of the AHP method with absolute measurement, it was possible to reach the final objective of the assessment, which was to order civil construction companies according to the materiality of their reports, based on specialists' opinions. However, through this method, it was possible to make other observations regarding the priorities of each criterion and sub-criterion. The same weightings were attributed to the economic, environmental, and social dimensions, corroborated by Elkington (1997) triple bottom line concept.

Within the economic dimension, the sub-criterion "Anticorruption" is of note, as it obtained the greatest weighting from specialists. This demonstrates the importance of this theme, possibly due to several cases of corruption within the civil construction sector which are increasingly investigated and reported in the media of several countries. Remaining in the ethical field, "Anti-competitive behavior" has the second greatest weighting within the economic dimension, confirming that experts are concerned about this issue. Authors such as Ameh \& Odusami (2010), Ameyaw et al. (2017), and Gunduz \& Önder (2013) point out that corruption and ethical deviations are endemic in the civil construction sector, due to the number of negotiations that take place that give rise to the potential for such abnormal behavior to occur, and the difficulties preventing project scrutiny. Of the reports observed, there were companies that did not disclose such topics (as shown in Table 4).

In relation to the environmental dimension, experts gave greater weight to the topic "Water", followed by "Effluents and Waste". As discussed previously, civil construction accounts for a large portion of water consumption on the planet, while it is responsible for generating significant amounts of solid waste on a global scale. The priority given to these topics by the experts questioned corroborates the available literature (Ecorys, 2014; Willmott Dixon, 2010). Despite the importance of these topics for civil construction, there were companies that neglected these matters in their reports.

In relation to the social dimension, experts gave greater weight to "Child Labor" and "Forced or Compulsory Labor", showing concerns about human rights violations, which for many years have been denounced by international organizations and comprises part of the UN Agenda 2030 (2015). Another concern of the experts related to "Occupational Health and Safety", given the high number of accidents and occupational diseases within the sector (Poghosyan et al., 2020; Trinh et al., 2019). Only one company studied these issues. However, "Child Labor" and "Forced or Compulsory Labor", despite being of concern to the consulted specialists, appear in only a few reports, demonstrating that there is potential for companies to become increasingly focused on these social issues.

For alternatives, the ranking obtained with the use of absolute measurement, according to the materiality of their reports in the view of experts, the following companies stand out: Cosapi (Peru) is ranked first with 0.129, followed by Concesión La Pintada (Colombia) with 0.126 in third place; and Comercializadora S\&E (Peru) appears in fourth place, with 0.083 .

The use of absolute measurement proved to be efficient, as it reduced the subjectivity of judgments, starting from the absolute data and reducing the number of assessments made by the decision makers in relation to the traditional AHP method. Another advantage is that the addition of other institutions to the assessment would not require new decisions to be made by the specialists.

Finally, the sensitivity analysis showed the consistency of the results, as in order to have a change in the ranking presented in this study, the weight of the criteria (dimensions) should vary by at least $11 \%$, in the case 
of the social dimension. In other cases, the variation should be 16\% and 20\% for economic and environmental dimensions, respectively.

\section{Conclusions}

This research aims to propose, apply, and discuss a model to evaluate the materiality of sustainability reports in the GRI Standards of civil construction companies in Latin America. The data presented in the survey were collected from sustainability reports published on the GRI website by the companies.

The importance of each sustainability topic was considered by experts, in relation to their relevance to the civil construction sector. The method used for this weighting was AHP, which is one of the best known and most used MCDM tools. To compare the relative materiality of the companies' reports, an absolute measurement approach was used. Through the AHP method, the problem was structured and divided into criteria, sub-criteria, and alternatives, allowing the development of a materiality ranking for the companies' sustainability reports.

The ranking obtained with the application of AHP with absolute measurement for the top three companies was Cosapi (Peru), followed by Concesión La Pintada (Colombia), and Comercializadora S\&E (Peru) appears in third place. The weightings attributed by the specialists are in accordance with what the literature deems fundamental in terms of sustainability for the civil construction sector. There is great potential to improve the quality of sustainability reports, as there are companies that fail to disclose pertinent topics in the experts' judgment.

The AHP method with absolute measurement proved to be efficient, particularly because it allows for weighting of criteria and sub-criteria, demonstrating that it can be useful for comparing the materiality of company reports through the classification of their available alternatives. Using sensitivity analysis, the method also makes it possible to show fluctuations of the results in response to variations in the weightings, depending on the degree of importance given to the criteria and sub-criteria. In addition, the use of the Expert Choice ${ }^{\circledR}$ program enabled efficient assessment, producing clear results and achieving the study objective.

One of the limitations of the AHP method observed in this research, apart from its subjectivity, is the fact that the knowledge of decision makers about the issues addressed is a fundamental variable pertaining to the quality of the results. Another limitation of the study was the lack of sustainability reports generated in large countries in the Latin American region, such as Brazil and Argentina. This meant that the number of potential reports relevant to the study was reduced. The sustainability topics were also analyzed from the perspective of specialists working in the civil and environmental construction sector, whereas other stakeholders are involved in broader processes of the companies studied.

For future work, it is suggested to use other MCDM methods to compare the materiality of sustainability reports produced by construction companies. It is proposed that the methodology in this study is adopted for such reporting in consecutive years, to determine whether the quality of sustainability reports, in terms of materiality, improves. It is recommended that companies incorporate the proposed method, to define with their stakeholders which sustainability topics are considered material for inclusion in sustainability reporting and to compare with other companies in the sector, assisting in the benchmarking process.

\section{References}

Ameh, O. J., \& Odusami, K. T. (2010). Professionals' ambivalence toward ethics in the Nigerian Construction Industry. Journal of Professional Issues in Engineering Education and Practice, 136(1), 9-16. http://dx.doi.org/10.1061/(ASCE) 1052-3928(2010) 136:1(9).

Ameyaw, E. E., Pärn, E., Chan, A. P. C., Owusu-Manu, D.-G., Edwards, D. J., \& Darko, A. (2017). Corrupt practices in the construction industry: survey of Ghanaian Experience. Journal of Management Engineering, 33(6), 5017006. http://dx.doi.org/10.1061/(ASCE) ME.1943-5479.0000555.

Bellantuono, N., Pontrandolfo, P., \& Scozzi, B. (2016). Capturing the Stakeholders' View in sustainability reporting: a novel approach. Sustainability, 8(4), 379. http://dx.doi.org/10.3390/su8040379.

Boral, S., Howard, l., Chaturvedi, S. K., McKee, K., \& Naikan, V. N. A. (2020). A novel hybrid multi-criteria group decision making approach for failure mode and effect analysis: An essential requirement for sustainable manufacturing. Sustainable Production and Consumption, 21, 14-32. http://dx.doi.org/10.1016/j.spc.2019.10.005.

Brooks, C., \& Oikonomou, l. (2018). The effects of environmental, social and governance disclosures and performance on firm value: A review of the literature in accounting and finance. The British Accounting Review, 50(1), 1-15. http://dx.doi.org/10.1016/j. bar.2017.11.005.

Calabrese, A., Costa, R., \& Rosati, F. (2015). A feedback-based model for CSR assessment and materiality analysis. Accounting Forum, 39(4), 312-327. http://dx.doi.org/10.1016/j.accfor.2015.06.002.

Calabrese, A., Costa, R., Levialdi, N., \& Menichini, T. (2016). A fuzzy analytic hierarchy process method to support materiality assessment in sustainability reporting. Journal of Cleaner Production, 121, 248-264. http://dx.doi.org/10.1016/j.jclepro.2015.12.005. 
Calabrese, A., Costa, R., Levialdi, N., \& Menichini, T. (2019). Materiality analysis in sustainability reporting: a tool for directing corporate sustainability towards emerging economic, environmental and social opportunities. Technological and Economic Development of Economy, 25(5), 1016-1038. http://dx.doi.org/10.3846/tede.2019.10550.

Cegan, J. C., Filion, A. M., Keisler, J. M., \& Linkov, l. (2017). Trends and applications of multi-criteria decision analysis in environmental sciences: literature review. Environment Systems \& Decisions, 37(2), 123-133. http://dx.doi.org/10.1007/s10669-017-9642-9.

Choudhury, S., Saha, A. K., \& Majumder, M. (2020). Optimal location selection for installation of surface water treatment plant by Gini coefficient-based analytical hierarchy process. Environment, Development and Sustainability, 22(5), 4073-4099. http://dx.doi. org/10.1007/s10668-019-00373-w.

Costa, R., \& Menichini, T. (2013). A multidimensional approach for CSR assessment: The importance of the stakeholder perception. Expert Systems with Applications, 4O(1), 150-161. http://dx.doi.org/10.1016/j.eswa.2012.07.028.

Durbach, 1. N., \& Stewart, T. J. (2012). Modeling uncertainty in multi-criteria decision analysis. European Journal of Operational Research, 223(1), 1-14. http://dx.doi.org/10.1016/j.ejor.2012.04.038.

Ecorys. (2014). Resource efficiency in the building sector: final report. Rotterdam: Copenhagen Resource Institute.

Edgley, C., Jones, M. J., \& Atkins, J. (2015). The adoption of the materiality concept in social and environmental reporting assurance: A field study approach. The British Accounting Review, 471), 1-18. http://dx.doi.org/10.1016/j.bar.2014.11.001.

Elkington, J. (1997). Cannibals with forks: The Triple Bottom Line of 21st Century Business. Oxford: Capstone.

Expert Choice ${ }^{\circledR}$. (2004). Expert Choice ${ }^{\circledR}$ Resource Aligner (Version 11). [Computer software]. Arlington: Expert Choice ${ }^{\circledR}$, Inc.

Global Reporting Initiative. (2013). G4 Sustainability reporting guidelines. Amsterdam: GRl.

Global Reporting Initiative. (2016). GRI 101: Foundation 2016. Amsterdam: GRl.

Global Reporting Initiative. (2018). G4 to Standards: Transition complete. Retrieved in 2020, March 14, from https://www.globalreporting. org/information/news-and-press-center/Pages/G4-to-Standards-transition-complete.aspx

Global Reporting Initiative. (2020). GRl's History. Retrieved in 2020, March 14, from https://www.globalreporting.org/information/ about-gri/gri-history/Pages/GRl's\%20history.aspx

Global Reporting Initiative. (2021a). About sustainability reporting. Retrieved in 2020, March 13, from https://www.globalreporting. org/information/sustainability-reporting/Pages/default.aspx

Global Reporting Initiative. (2021b). Sustainability disclosure database. Retrieved in 2020, March 13, from http://database.globalreporting.org

Govindan, K., Diabat, A., \& Madan Shankar, K. (2015a). Analyzing the drivers of green manufacturing with fuzzy approach. Journal of Cleaner Production, 96, 182-193. http://dx.doi.org/10.1016/j.jclepro.2014.02.054.

Govindan, K., Rajendran, S., Sarkis, J., \& Murugesan, P. (2015b). Multi criteria decision making approaches for green supplier evaluation and selection: A literature review. Journal of Cleaner Production, 98, 66-83. http://dx.doi.org/10.1016/j.jclepro.2013.06.046.

Gunduz, M., \& Önder, O. (2013). Corruption and Internal Fraud in the Turkish Construction Industry. Science and Engineering Ethics, 19(2), 505-528. http://dx.doi.org/10.1007/s11948-012-9356-9. PMid:22371033.

Kucukvar, M., Noori, M., Egilmez, G., \& Tatari, O. (2014). Stochastic decision modeling for sustainable pavement designs. The International Journal of Life Cycle Assessment, 19(6), 1185-1199. http://dx.doi.org/10.1007/s11367-014-0723-4.

Lai, A., Melloni, G., \& Stacchezzini, R. (2017). What does materiality mean to integrated reporting preparers? An empirical exploration. Meditari Accountancy Research, 25(4), 533-552. http://dx.doi.org/10.1108/MEDAR-02-2017-0113.

Liu, B., Zhang, L., Sun, J., Wang, D., Liu, C., Luther, M., \& Xu, Y. (2020). Composition of energy outflows embodied in the gross exports of the construction sector. Journal of Cleaner Production, 248, 119296. http://dx.doi.org/10.1016/j.jclepro.2019.119296.

Man, Y., Han, Y., Liu, Y., Lin, R., \& Ren, J. (2020). Multi-criteria decision making for sustainability assessment of boxboard production: A life cycle perspective considering water consumption, energy consumption, GHG emissions, and internal costs. Journal of Environmental Management, 255, 109860. http://dx.doi.org/10.1016/j.jenvman.2019.109860. PMid:31759200.

Mancini, L., \& Sala, S. (2018). Social impact assessment in the mining sector: Review and comparison of indicators frameworks. Resources Policy, 57, 98-111. http://dx.doi.org/10.1016/j.resourpol.2018.02.002.

Manzardo, A., Ren, J., Piantella, A., Mazzi, A., Fedele, A., \& Scipioni, A. (2014). Integration of water footprint accounting and costs for optimal chemical pulp supply mix in paper industry. Journal of Cleaner Production, 72, 167-173. http://dx.doi.org/10.1016/j. jclepro.2014.03.014.

Martin-Utrillas, M., Reyes-Medina, M., Curiel-Esparza, J., \& Canto-Perello, J. (2014). Hybrid method for selection of the optimal process of leachate treatment in waste treatment and valorization plants or landfills. Clean Technologies and Environmental Policy, 17(4), 873-885. http://dx.doi.org/10.1007/s10098-014-0834-4.

Moggi, S. (2019). Social and environmental reports at universities: a Habermasian view on their evolution. Accounting Forum, 43(3), 283-326. http://dx.doi.org/10.1080/01559982.2019.1579293.

Mohammed, A. (2020). Towards "gresilient" supply chain management: A quantitative study. Resources, Conservation and Recycling, 155, 104641. http://dx.doi.org/10.1016/j.resconrec.2019.104641.

Ocampo, L. A. (2018). Correction to: Applying fuzzy AHP-TOPSIS technique in identifying the content strategy of sustainable manufacturing for food production. Environment, Development and Sustainability, 21(6), 3121-3122. http://dx.doi.org/10.1007/s10668-018-0188-x.

Petrillo, A., Carotenuto, P., Baffo, 1., \& De Felice, F. (2017). A web-based multiple criteria decision support system for evaluation analysis of carpooling. Environment, Development and Sustainability, 20(5), 2321-2341. http://dx.doi.org/10.1007/s10668-017-9991-z.

Poghosyan, A., Manu, P., Mahamadu, A.-M., Akinade, O., Mahdjoubi, L., Gibb, A., \& Behm, M. (2020). A web-based design for occupational safety and health capability maturity indicator. Safety Science, 122, 104516. http://dx.doi.org/10.1016/j.ssci.2019.104516.

Rahman, M., Islam, R., Wan Husain, W. R., \& Ahmad, K. (2019). Developing a hierarchical model to enhance business excellence in hotel industry of Bangladesh. International Journal of Contemporary Hospitality Management, 31(4), 1836-1856. http://dx.doi. org/10.1108/1JCHM-02-2018-0110. 
Ramanathan, R., \& Ganesh, L. S. (1994). Group preference aggregation methods employed in AHP: An evaluation and an intrinsic process for deriving members' weightages. European Journal of Operational Research, 79(2), 249-265. http://dx.doi.org/10.1016/03772217(94)90356-5.

Reimsbach, D., Schiemann, F., Hahn, R., \& Schmiedchen, E. (2019). In the Eyes of the Beholder: Experimental Evidence on the Contested Nature of Materiality in Sustainability Reporting. Organization \& Environment, 33(4), 624-651. http://dx.doi.org/10.1177/1086026619875436.

Saad, M. H., Nazzal, M. A., \& Darras, B. M. (2019). A general framework for sustainability assessment of manufacturing processes. Ecological Indicators, 97, 211-224. http://dx.doi.org/10.1016/j.ecolind.2018.09.062.

Saaty, T. L. (1980). The analytic hierarchy process. New York: McGraw-Hill.

Saaty, T. L. (2006). Rank from comparisons and from ratings in the analytic hierarchy/network processes. European Journal of Operational Research, 168(2), 557-570. http://dx.doi.org/10.1016/j.ejor.2004.04.032.

Saaty, T. L. (2008). Decision making with the analytic hierarchy process. International Journal of Services Sciences, 1(1), 83. http:// dx.doi.org/10.1504/1JSSCl.2008.017590.

Safari, M., \& Areeb, A. (2020). A qualitative analysis of GRl principles for defining sustainability report quality: an Australian case from the preparers' perspective. Accounting Forum, 44(4), 1-32. http://dx.doi.org/10.1080/01559982.2020.1736759.

Schlickmann, M. N., Ferreira, J. C. E., \& Pereira, A. C. (2020). Method for assessing the obsolescence of manufacturing equipment based on the triple bottom line. Production, 30, e20190003. http://dx.doi.org/10.1590/0103-6513.20190003.

Schmeltz, L. (2014). Introducing value-based framing as a strategy for communicating CSR. Social Responsibility Journal, 10(1), 184206. http://dx.doi.org/10.1108/SRJ-06-2012-0065.

Simanaviciene, R., \& Ustinovichius, L. (2010). Sensitivity Analysis for Multiple Criteria Decision Making Methods: TOPSIS and SAW. Procedia: Social and Behavioral Sciences, 2(6), 7743-7744. http://dx.doi.org/10.1016/j.sbspro.2010.05.207.

Spangenberg, J. H. (2016). Hot Air or Comprehensive Progress? A Critical Assessment of the SDGs. Sustainable Development, 25(4), 311-321. http://dx.doi.org/10.1002/sd.1657.

Talbot, D., \& Boiral, O. (2018). GHG Reporting and Impression Management: an assessment of sustainability reports from the energy sector. Journal of Business Ethics, 147(2), 367-383. http://dx.doi.org/10.1007/s10551-015-2979-4.

Tramarico, C. L., Karpak, B., Salomon, V. A. P., da Silveira, C. A. M., \& Marins, F. A. S. (2019). Multi-criteria analysis of professional education on supply chain management. Production, 29, e20180087. http://dx.doi.org/10.1590/0103-6513.20180087.

Trinh, M. T., Feng, Y., \& Mohamed, S. (2019). Framework for measuring resilient safety culture in Vietnam's Construction Environment. Journal of Construction Engineering and Management, 145(2), 4018127. http://dx.doi.org/10.1061/(ASCE)C0.1943-7862.0001602.

United Nations. (2015). Transforming Our World: the 2030 Agenda for Sustainable Development. New York: UN.

Wagner, R., \& Seele, P. (2017). Uncommitted deliberation? Discussing Regulatory Gaps by Comparing GRI 3.1 to GRI 4.0 in a Political CSR Perspective. Journal of Business Ethics, 146(2), 333-351. http://dx.doi.org/10.1007/s10551-017-3654-8.

Wicher, P., Zapletal, F., \& Lenort, R. (2019). Sustainability performance assessment of industrial corporation using Fuzzy Analytic Network Process. Journal of Cleaner Production, 241, 118132. http://dx.doi.org/10.1016/j.jclepro.2019.118132.

Willmott Dixon. (2010). The Impacts of Construction and the Built Environment. Retrieved in 2020, March 14, from https://www. willmottdixon.co.uk/asset/9462/download

World Commission on Environment and Development. (1987). Our Common Future. Oxford: Oxford University Press.

Yan, H.-B., \& Ma, T. (2015). A group decision-making approach to uncertain quality function deployment based on fuzzy preference relation and fuzzy majority. European Journal of Operational Research, 241(3), 815-829. http://dx.doi.org/10.1016/j.ejor.2014.09.017.

Yu, A., Jia, Z., Zhang, W., Deng, K., \& Herrera, F. (2020). A dynamic credit index system for TSMEs in China using the Delphi and Analytic Hierarchy Process (AHP). Methods. Sustainability, 12(5), 1715. http://dx.doi.org/10.3390/su12051715.

Zhao, B., Tang, T., \& Ning, B. (2016). Applying hybrid decision-making method based on Fuzzy AHP-WOWA operator for emergency alternative evaluation of unattended train operation metro system. Mathematical Problems in Engineering, 2016, 1-12. http:// dx.doi.org/10.1155/2016/4105079.

Ziout, A., Azab, A., Altarazi, S., \& ElMaraghy, W. H. (2013). Multi-criteria decision support for sustainability assessment of manufacturing system reuse. CIRP Journal of Manufacturing Science and Technology, 6(1), 59-69. http://dx.doi.org/10.1016/j.cirpj.2012.10.006. 